\title{
Analisis HACCP Pada UKM Minuman Siap Saji Aloe Vera (ALOJA) Sebagai Sarana Memenuhi Standar Produksi Pangan Yang Baik
}

\section{HACCP Analysis in Aloe Vera's Ready to Serve Drink (ALOJA) as A Way to Meet Good Manufacturing Standard for Food}

\author{
Dimas Bayu Pinandoyo * 1, Asriadi Masnar²
}

\begin{abstract}
ABSTRAK
Latar Belakang: Pada tahun 2017 BPOM menyebutkan bahwa Industri Kecil Makanan berkontribusi terhadap 49,5\% kasus keracunan pangan di Indonesia. Pemerintah melalui UU No. 18 Tahun 2012 telah mengatur mengenai prosedur pengolahan pangan yang baik (CPPB). ALOJA sebagai UKM produsen minuman siap saji Aloe vera memiliki keterbatasan dalam saranaprasarana dan SDM sehingga pemenuhan standar produksi pangan yang baik sulit untuk diterapkan. Analisis HACCP perlu diterapkan untuk memberikan masukan dalam penyusunan SOP dalam alur produksinya sehingga memenuhi standar produksi pangan yang baik.

Tujuan: Penelitian ini bertujuan untuk melakukan analisis dan menetapkan aturan HACCP sebagai bahan rekomendasi dalam penyusunan SOP yang memenuhi persyaratan standar produksi pangan yang baik.

Metode: Metode yang digunakan dalam penelitian ini adalah dengan menerapkan 7 dari 14 langkah dalam HACCP. Metode penilaian didasarkan pada keparahan (Severity) skala tiga dan tingkat kemungkinan terjadinya (probability) skala 3. Rekomendasi SOP disusun pada resiko medium hingga tinggi yang diperoleh dari matriks severity vs probability.

Hasil: Dalam analisis HACCP ini ditemukan bahwa tahap yang masih memiliki resiko menengah ke atas adalah tahap pengendalian hama, pencucian dan perendaman, pendinginan, dan pengemasan-penyegelan. Rekomendasi yang diberikan adalah dengan menambahkan jala nilon ukuran 80 mesh pada ventilasi udara dan melakukan pengecekan rutin terhadap kondisi jala nilon pengontrolan konsentrasi kapur sirih yang digunakan, dengan menyusun regulasi yang ketat untuk ruang pendinginan, dan penerapan kondisi aseptis atau minimal dengan adanya penyuci hama untuk tangan, masker, penutup kepala, apron yang bersih, dan kaki yang bersih.

Kesimpulan: Rekomendasi SOP diberikan pada proses pengendalian hama, pencucian dan perendaman, pendinginan, dan pengemasan-penyegelan.
\end{abstract}

Kata kunci: Keamanan Pangan, HACCP, Industri Kecil, CPPB, Aloe vera, Minuman Siap Saji

\section{ABSTRACT}

Background: BPOM stated that in 2017, small and micro food enterprises were responsible for $49.5 \%$ food borne disease in Indonesia. Indonesian government had provided guidance about good handling standard for food product (GMP) by UU No.18 Year 2012. ALOJA as Small and Medium Enterprise (SME) had lot of limitation to meet the standard. HACCP analysis was needed to give recommendation in arranging SOP that meet the standard.

Objectives: The objective of this research was to do and set HACCP analysis as a way to collect data to give recommendation in setting the Standard Operating Procedure (SOP) that meet food safety regulation.

Methods: This research was done by applying 7 of 14 steps in HACCP implementation. Judgment taken based on the level of severity ( 3 level) and level of occurrence probability ( 3 level). From the matrix derived from it, SOP recommendation was taken if the level of control was medium and above.

Results: The results showed that pest control procedure, washing and dipping, cooling, packaging and sealing process was on medium risk or above. SOP recommendation was done by adding nylon net sized 80 mesh and check it regularly, control the concentration of lime betel, limit and regulate the cooling room strictly, and to apply aseptic condition. If this not possible, the best option was to apply washing hand and feet procedure with soap/hand sanitizer, masker, cover the hair of worker during packaging and sealing.

Conclusions: Recommendation was given for Pest Control procedure, washing and dipping, cooling, packaging and sealing process.

Keywords: Food Safety, HACCP, SME, GMP, Aloe vera, Ready to Serve Beverages 


\author{
*Correspondent: \\ dimas.pinandoyo@polimedia.ac.id (*) \\ Dimas Bayu Pinandoyo $(*)$ \\ Politeknik Negeri Media Kreatif, Jl. Srengseng Sawah Raya No.17, Jakarta Selatan, Daerah Khusus Ibukota Jakarta
}

\section{INTRODUCTION}

Foodborne illness and diseases have been a problem for food industry in the long term. World Health Organization (WHO) predicted that in South East Asia in 2015 at least 1750.00 people died because of foodborne illness ${ }^{1}$. In Indonesia in 2016 BPOM (Indonesian National Agency of Drug and Food Control) stated that at least 5,673 cases of foodborne diseases was recorded, 3,351 among them were hospitalized, and 7 were reported to passed away². In 2017, BPOM stated that small and medium enterprises (SMEs) of food industry responsible for $49,5 \%$ of foodborne diseases ${ }^{3}$.

Food SMEs (Small and Medium Enterprise) have many limitations that hinder them to apply standard that meet food safety standard requirements. However, food safety is the right of consumers. Indonesian government had released the regulation UU No.18 Year 2012 considering good handling standard for food product based on $\mathrm{GMP}^{4}$. The regulation later on improvised with Peraturan BPOM No.31 Year 2018 which in clause number 36 stated that most of the food product must attached MD distribution permit to allowed to be marketed ${ }^{5}$. MD distribution permit consist list of HACCP that should be met by food industry. However, the standard seems to be a burden for Small and Medium Enterprise.

HACCP was initially created by NASA to ensure pathogen free environment for space travel. However, since the outbreak of Escherichia coli 0157:H7 and Bovine Spongiform Encephalopathy (BSE) around 1993, HACCP became one of model required to be implemented to ensure food safety for consumer ${ }^{6}$. HACCP implementation is a big challenge even in implementation of Culture Excellence assessment tools ${ }^{7}$. Applying HACCP however, cost only $0,5 \%$ of production costs, while the benefit from applying HACCP was $1,5 \%$ of production costs $^{8}$. Implementing HACCP in small and medium food enterprise increase the safety-especially in microbial aspect of SME's food product until 99,6 \% ${ }^{9}$. Although considered as hard to implement especially in SME level, HACCP proved bring benefit in short and long term. HACCP implementation in Thailand result a good expectation in term of social legitimacy, economic competitiveness, and commitment in food safety. They also suggested that the companies already succeed in implementing HACCP should train other smaller food companies about HACCP in limited extend ${ }^{10}$. In Philippine, although SME had many limitations, Philippine's Department of Trade and Industry released a program called Department of Trade and Industry Accreditation Program to train and implement HACCP in SME voluntary. It was claimed that this program succeeds in opening opportunity in product quality improvement, consumer protection, export opportunities, and maximize company's profit ${ }^{11}$.
Poland succeed in implementing HACCP in SME. The key was simplification of HACCP in some areas such as flow diagram, hazard analysis, documented procedure and record ${ }^{12}$. However, during evaluation of HACCP implementation by employees and staffs, it was revealed that there was $60 \%$ of deviation reflecting lack of HACCP training and information ${ }^{13}$. Although some areas of HACCP can be simplified, and training was regularly given to the employees, a team or person having scientific expertise still needed in implementing HACCP in SME of food industry ${ }^{14}$.

ALOJA is an SME producing ready to serve beverages in Koja Sub District, North Jakarta. ALOJA was initiated by PERTAMINA as their Corporate Social Responsibility program and assisted by PKPU Human Initiative. ALOJA had succeed in women empowerment by enriching the knowledge of housewives about the utilization of Aloe Vera as ready to serve beverages material. However, in implementing HACCP, they still need assistance from an expert with scientific expertise. The objective of this research was to do HACCP analysis as a way to collect data to give recommendation in set the SOP that meet food safety standard regulation. Regardless the limitation, this research was vital to ensure that food product produced by ALOJA SME is safe to drink.

\section{METHOD}

HACCP content of 12 main steps. 7 main steps were applied in this research, which were:

- HACCP team assembly

- Product description

- Description the intended consumer and how it will be consumed

- Arrangement of the production diagram flow

- The diagram on site verification

- Hazard Analysis implementation

- Determination of the Critical Control Point

The analysis was conducted by measuring level control based on matrix of severity ( 3 level point) and probability ( 3 level point). In term of severity, the level of severity describes with score/level as bellow,

1. Score 1 was given to low severity, when the hazard only causing pain but let the victim doing activity normally

2. Score 2 was given to medium severity, when the victim had to hospitalized

3. Score 3 was given to high severity, that may lead to severe illness or even dead.

Level of probability was described as bellow,

1. Score 1 was given to low occurrence, with probability of occurrence 5 times in a year and below

2. Score 2 was given to medium/middle occurrence, with probability of occurrence 5-10 times in a year 
3. Score 3 was given to high occurrence, with probability of occurrence more than 10 times in a year

Matrix of level control was derived from the score given above as shown in Image 1. If the level of control in medium risk area and above, the recommendation of SOP then taken. The judgment done by observing the real condition of SME. The recommendation taken by implementing $7^{\text {th }}$ step in HACCP that was identification of Critical Control Point. The model that being used was Karagozlu et al. (2009) model ${ }^{15}$. The diagram flow of Critical Control Point identification was described in Image 2. The research was being done in ALOJA Production Site, Jl. Sindang No. 1 RT 5/RW 9, Koja, Jakarta Utara, 14220. The research was conducted during month September 2019.

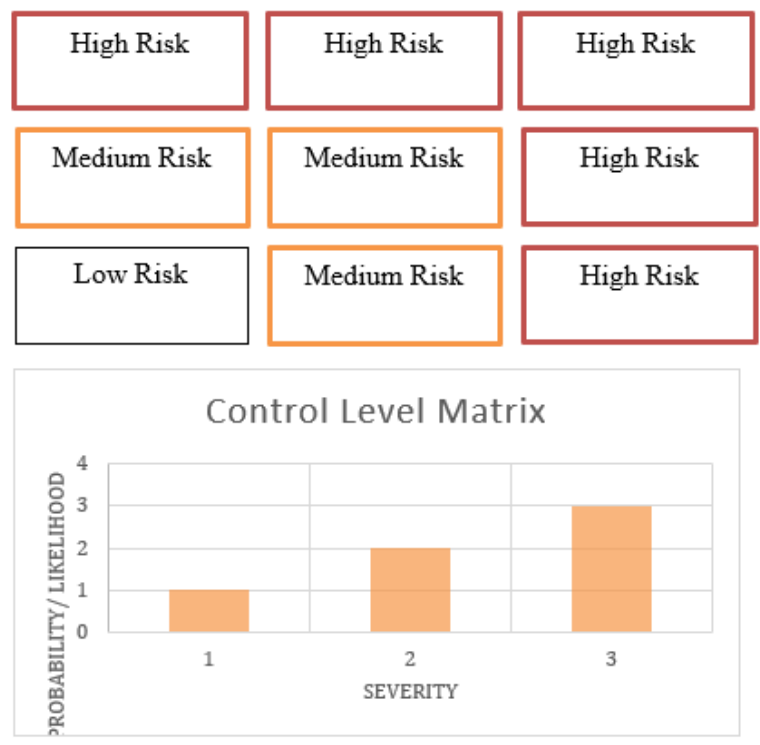

Image 1. Control Level Determination Matrix

\section{RESULTS AND DISCUSSION}

In this research, the HACCP team consisted of people with Food Science and Technology background (Dimas Bayu Pinandoyo), Food Packaging Background (Asriadi Masnar), and Public Health background (Asri Permata Sari). HACCP Team should consist of people with different background to minimize the weakness in system that applied HACCP system ${ }^{16}$. Ideally, A HACCP team consist of 5-10 people, with multidisciplinary background, and applied inter-hierarchical approach ${ }^{17}$. However, in small and medium enterprise, less amount was allowed as long as they have proper HACCP training durability ${ }^{18}$.

The second step that been done in this research was product description. In this research, ALOJA Aloe vera ready to drink (RTS) beverages described as beverages that contain at least $10 \%$ of Aloe vera juice or slices, consist of Aloe vera pulp, sugar, and water. The taste was sweet with sensation of chewy in term of mouth-feel. Natrium Benzoate was used as preservative with concentration $0,5 \mathrm{~g} / \mathrm{l}$. It has at least 2 months of shelf life, and better stored and served in cold condition. Intended consumer was common consumer from all generation with medium to low budget. Aloe vera RTS was claimed with high potential of nutrient content, and can preserve it for 90 days $^{19}$. It also found that Aloe vera RTS was fit and recommended for large scale production industrial level20.

The result of production diagram flow arranged in this research was shown in image 3 . The diagram flow was then being verified to conduct hazard analysis. The observation result shown the diagram was practiced properly. Hazard analysis was done using Control Level Determination Matrix. Control Level Determination Matrix of this research shown on image 4.

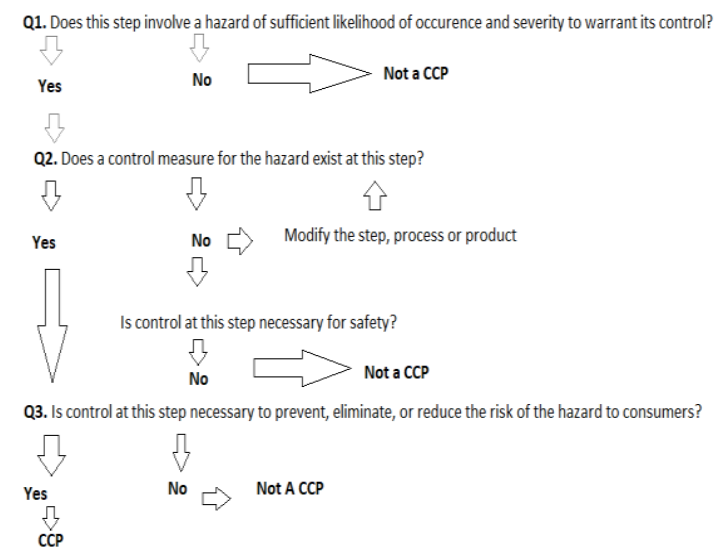

Image 2. Critical Control Point Decision Tree

Most of the aspects especially those written on the diagram flow considered to have low risk. It was shown by the level control of it. Most of the aspects had 1 level of control means most of them were in low risk level. Five aspect needed a proper concern, those were Pest Control, Cooling, Packaging (Especially during filling), Sealing, and the use of Additive. Pest Control and Additive had 2 level of control, while Cooling, Packaging and Sealing had 4. It means Pest Control, Cooling, Packaging, Sealing, and Additive were on medium and above risk level. Control Level Determination Matrix was ideal for mapping the problem of the processes in food industry. It shows overall image of control level in every processes in the industry. However, for HACCP analysis the matrix was considered to be complicated one. To simplify the display, the control level will be shown by table of severity multiplied by probability/likelihood. If the result -shown as control level- was 2 and above, a recommendation will be arranged. The result was shown in table $1 . \quad$ There's lot of requirement considering a proper place/location of production that meet HACCP requirement. In this research, since the unit of production categorized as Small and Medium Enterprise (SME), the regulation that being used as preference for the standard was BPOM RI No. HK.03.1.23.04.12.2206 Year 2012 ${ }^{21}$. The location of ALOJA SME was clean, free from waste, bad odor, smoke, and dust. Although located in middle of city, location was situated in the corner of Koja Village Office, that's why it create enough barrier with public settlement. Waste management and cleaning management was being managed according to Working and Utensil Cleaning SOP. Cleaning was performed at least a day before production, 
and after production. Waste in form of Aloe vera outer leaf was being used as green manure to fertilize village's field just next to production location. One person was in charge for sewage and waste management. Cleaning SOP cover all the possible treatment needed to protect production area especially from dust and biological contaminant. Roof and wall was being cleaned using broom to remove dust and spider nests. Glasses surfaces was being cleaned regularly using disinfectant agent (market named of the disinfectant: "Cling") to clean the surfaces from dust and mushrooms, and floor was being swept and mopped regularly with disinfectant agent (market named "Wipol"). Place/location was included in HACCP analysis since it one of the important aspect of food safety. No matter how the PRP was being set, if the environment had a very high risk to deliver contaminant to product, then the probability/likelihood of contamination in all process of production will increase ${ }^{22}$.

Raw Material Input

Washing and Cutting<smiles>[Te]</smiles>

Stored in closed clean container to distributed
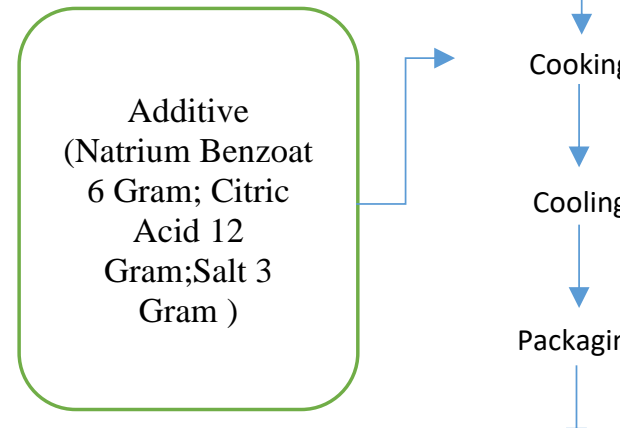

Sugar $(1,5 \mathrm{Kg})$

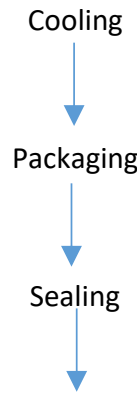

Batch coding<smiles>[CH]1CC1</smiles>

Stored $\longrightarrow$ Marketing

\section{Image 3. Aloe vera RTS production Diagram Flow}

Premises and room of ALOJA SME was arranged in 4 main rooms, that was production room for washing, dipping, grinding, and cooking, Washing room, storage room where cooling, filling, sealing, and storage was being done, and the last was display room. Although washing, dipping, grinding, and cooking was being done in one room, there was a brief line drawn on floor to separate each area and provide enough movement space so that movement of workers from one process to others can be minimized. This is very important to prevent cross contamination. Cooling and storage chamber was being monitored strictly, since this place is the key of the quality of final product. Movement of worker in and out was being monitored by check list that attached in front of the door. Unauthorized people was prevented to enter the cooling and storage room to prevent cross contamination. As described rooms and utensils were being cleaned regularly. Thus, premises and room, also equipment was described to have a low risk level control (Image 5).

Water supply of ALOJA analyzed at low risk level 
control. Water supply of ALOJA SME was from PDAM (Government Regional District Water Supply Enterprise). PDAM is managed by government with several set of quality standard, most of it was set by PERMEN PU No.18/PRT/M/2007. Controversy still arise regarding the quality of water since based on the same regulation, each region may develop their own standard to adjust with each region's resource. To ensure that product of ALOJA still meet the food safety standard, water from PDAM only used for cleaning and washing, while for RTS material, ALOJA used commercial drinking water with market name "AQUA" or at least refill of commercial drinking water. Control level in this process was PRP (PreRequisite Program).

Pest control of ALOJA SME has been set with a proper barrier to minimize the possibility of pest from neighboring to enter the production site. The high and tick wall was set around the production site that prevent rodent to enter the production place. Shrub was being cut, and weeds was being cleaned regularly to prevent a medium for pest nest or growth. However, there's still no proper barrier or filter on the ventilation system. This bring the possibilities for some insects or pest to enter the production site. Insect had a potential to be a vector for many diseases. Flies are potential for digestion diseases. Cockroach initially considered as neutral, but since their exposure to likely contaminated area like sewages, garbage bins, etc, they are prone to be cross contamination agent especially for bacteria and fungi. Likelihood of these vector was small (scored one) during the observation since room was being cleaned regularly, but the severability was medium, especially for flies since it may cause diarrhea and event dysentery (scored two). Pest control of ALOJA SME fell under medium control level. Although not categorized as CCP (Critical Control Point), a proper OPRP (Operational Pre-Requisite Program) should be set.

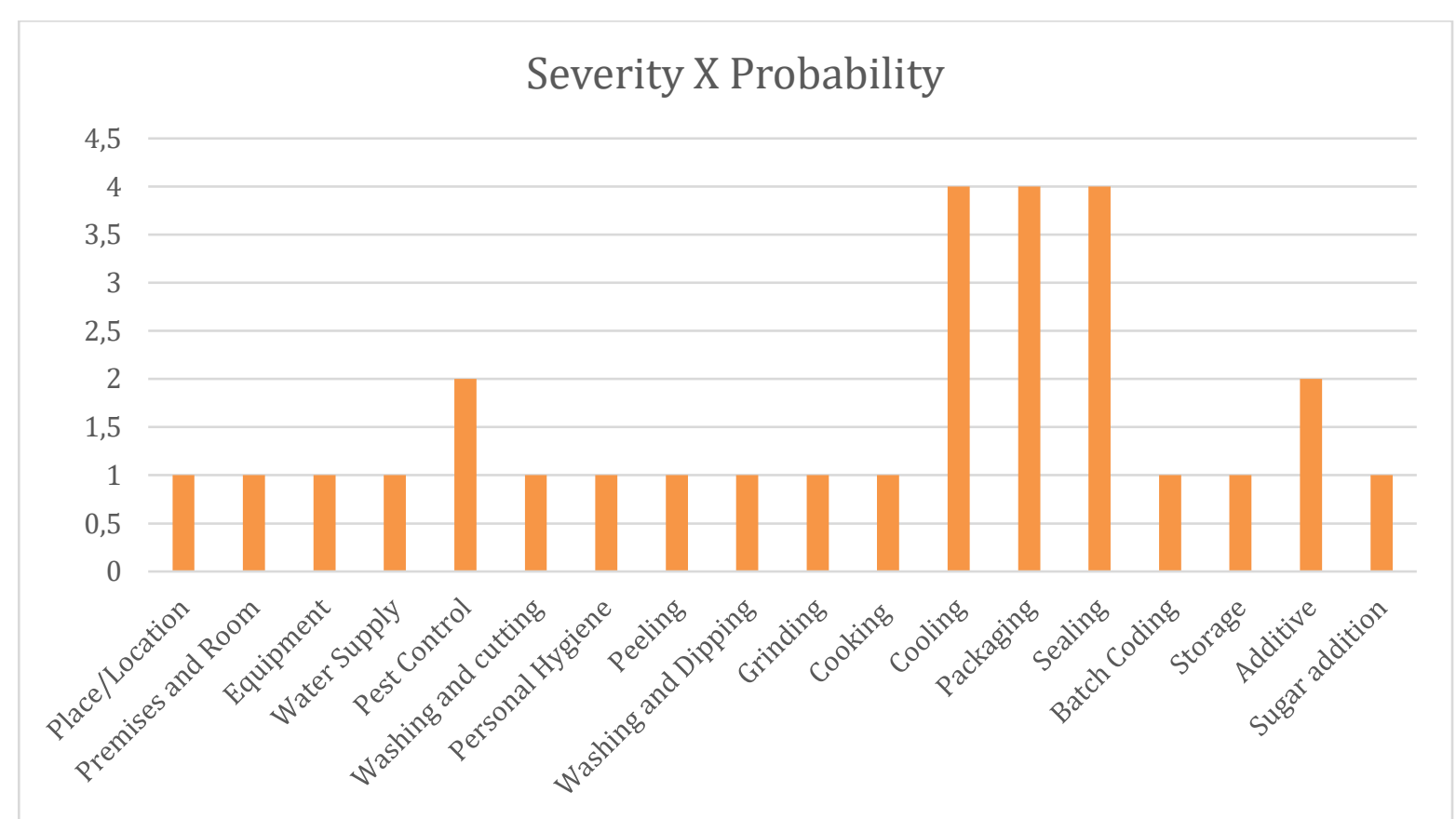

Image 4. Control Level Determination Matrix of ALOJA SME

Personal hygiene was being set properly. The worker was strictly ordered to wear the protection clothes while working. Procedure of washing hand and feet with soap was set before and after every process. Worker was not allowed to wear jewelries, nail polish, or keep long nail when working. No sick worker was allowed to enter the production site. FAO in its Food Handler Manual set standard that Food Handler must be in optimum health condition while working. No respiratory problem, stomach illnesses, wounds, infections, or any related condition allowed. The manual also set that food handler should wash their hands properly with cleanrunning water and soap before and after handling. If food handler involved in any activity that likely caused contamination, same procedure must be repeated. Food handler suggested to take a proper shower before going to work. They also should keep their nails trimmed and clean, the face shaven, covered, or groomed, and the hair should be washed and bound under a cap or scarf. During the analysis, all of the worker practice this regulation. They also suggested to avoid scratching or cleaning nose, mouth, hair, ears, pimples, and wound when working, handling food with bare hands instead of utensils, using their cloth as cleaning or drying cloth, leaving the production site or enter the washroom while wearing the protective clothes, smoking and eating inside the production site. Personal hygiene of ALOJA SME was categorized as low risk control level. Preventive procedure was done using PRP and OPRP.

Washing and cutting of raw material was applied to reduce the microbial load of raw material and remove physical hazard like debris, soil, and another physical hazard from field. Washing also reduce or remove unwanted chemical hazard from field, especially water dissolved chemical material. Cutting was performed to remove unwanted or damaged part of raw material. Ideally washing performed under high pressure running water. In ALOJA, high pressure running water was not

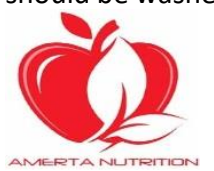

(C)2020. Pinandoyo, Masnar. Open access under CC BY - SA license.

Received:18-12-2019, Accepted: 09-03-2020, Published online: 29-09-2020.

doi: 10.20473/amnt. v4i3.2020.205-212. Joinly Published by IAGIKMI \& Universitas Airlangga 
available. OPRP and PRP set in ALOJA was designed to encounter this limitation. PRP and OPRP was arranged in Raw Material Intake SOP. This SOP enlist details of procedure, the requirements of raw material intake was also described here. Most of the time, raw material was taken from village Aloe vera field. But just in case ALOJA had to input raw material from outside, the SOP set the quality should not differ significantly from raw material harvested from their field. Procedures for washing and cutting of raw material ensure that water used for washing were clean and running strongly, the worker met the requirement of personal hygiene standard, brushing procedure was performed gently repeatedly to ensure the removal of physical, chemical hazard and reduce the microbial load. The transfer of raw material also being done in clean closed container. Washing and cutting process was categorized as low risk control level.

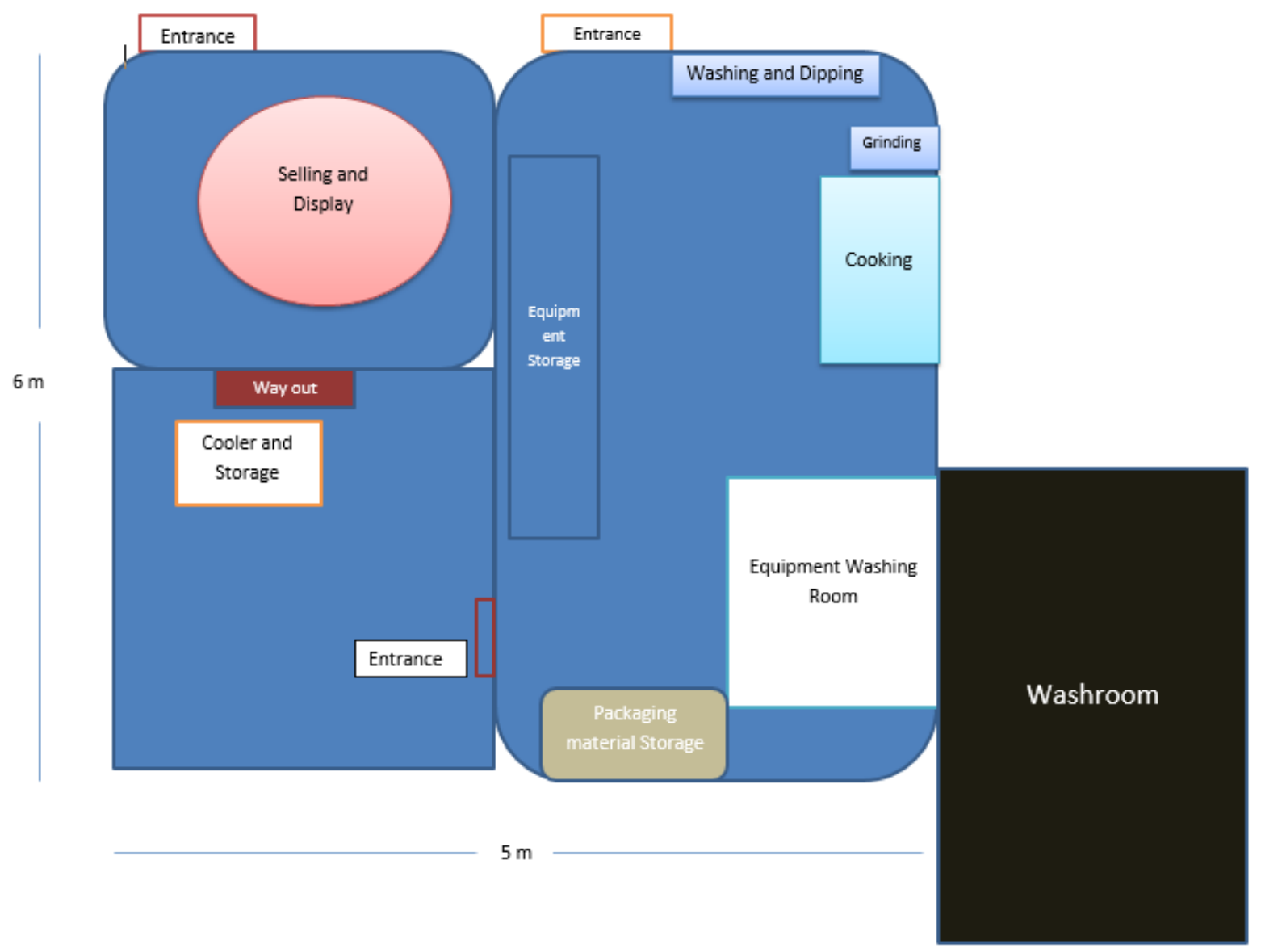

Image 5. Premises and Location Design of ALOJA SME

The key of judgment in matrix of control level in this research based on the SOP of ALOJA in every processes. Further analysis only done to processes with medium and above control level risk was shown in table 2.

The reference used in this research was SNI 7388:2009 about the limitation of microbial hazard in food product ${ }^{23}$. Microbial hazard potential was identified in cooling. As and SME, ALOJA still had no facilities for hot filling. Since the packaging material was PET plastic bottle, they need to cool it first before filling. Unfortunately, there was no proper procedure to ensure during cooling process the product was not contaminated by microorganism. They left the product in open container in clean room and wait it till it cooled. The SOP and control measure recommendation that being set in analysis were to ensure there's no direct and cross contamination from the worker and environment to the product. Since ALOJA also not having a packaging and sealing machine, the process was being done manually. Hence, this point is critical to ensure that during packaging and sealing, worker was on aseptic condition. If aseptic condition was unable to perform, the option was to ensure there were hand sanitizer, masker, clean head cap, apron, and clean feet. As per chemical hazard, the risk was found during washing and dipping. During the analysis, the used of lime betel was not controlled properly. For the SOP recommendation, the reference of the limit was research that being done by Yunus et $a^{24}$. While for pest control is set according to Food Manual handler of $\mathrm{FAO}^{25}$. Suggestion was being made to ensure that the facilities and equipment was properly maintained to prevent for nesting or interfering the workplace. 


\section{CONCLUSION}

The result of HACCP analysis in ALOJA SME shown that pest control procedure, washing and dipping process, cooling process, and packaging and sealing process have medium to high level of risk. SOP recommendation for pest control was done by adding nylon net sized 80 mesh and periodic check. SOP recommendation for washing and dipping process was set to control the concentration of lime betel to ensure the limit of lime betel still in safe level. For cooling process, the SOP recommendation was performed to limit and regulate the cooling room strictly to ensure the room stay in clean condition and free from contamination risk. For packaging and sealing process, the recommendation was set to apply aseptic condition during packaging and sealing, if this not possible, the best option was to apply washing hand and feet procedure with soap/hand sanitizer, using masker and cap during packaging and sealing to prevent cross contamination. Regardless the limitation, ALOJA SME had a good control for food safety procedure and can be used as model for other SME producing RTS food and beverages. ALOJA Aloe Vera is recommended for large production.

\section{ACKNOWLEDGEMENT}

Writers would like to express gratitude to Pertamina to permit us to conduct the research, PKPU Human Initiative to give us lot of support during research, and the worker of ALOJA SME to give us such cooperative respond during the course of this research.

\section{REFERENCE :}

1. WHO (World Health Organisation). World Health Day 2015: Food Safety. https://www.who.int/campaigns/world-healthday/2015/fact-sheet.pdf (2015).

2. BPOM (Badan Pengawas Obat dan Makanan). Laporan Tahunan 2016. (2016).

3. BPOM (Badan Pengawas Obat dan Makanan). Laporan Tahunan 2017. https://www.pom.go.id/new/admin/dat/20180 710/Laporan Tahunan BPOM 2017.pdf (2017).

4. Presiden Republik Indonesia. Undang-Undang Republik Indonesia No. 18 Tahun 2012. http://www.bulog.co.id/dokumen/pp/PP_17_2 015_KPG.pdf (2012).

5. BPOM (Badan Pengawas Obat dan Makanan). Peraturan Badan Pengawas Obat dan Makanan Nomor 31 Tahun 2018 Mengenai Label Pangan Olahan. (2018).

6. Weinroth, M. D., Belk, A. D. \& Belk, K. E. History, development, and current status of food safety systems worldwide. Anim. Front. 8, 9-15 (2018).

7. Zaida, T. J. The development of a safety and quality culture assessment tool from a longitudinal, mixed-method research journey. Worldw. Hosp. Tour. Themes 10, 313-329 (2018).

8. Cusato, S. et al. Assessing the costs involved in the implementation of GMP and HACCP in a small dairy factory. Qual. Assur. Saf. Crop. Foods 6, 135-139 (2014).

9. Doménech, E., Amorós, J. A., Pérez-Gonzalvo, M. \& Escriche, I. Implementation and effectiveness of the HACCP and pre-requisites in food establishments. Food Control 22, 1419-1423 (2011).

10. Arpanutud, P., Keeratipibul, S., Charoensupaya, A. \& Taylor, E. Factors influencing food safety management system adoption in Thai foodmanufacturing firms: Model development and testing. Br. Food J. 111, 364-375 (2009).

11. Teves, K. L. Y. HAZARD ANALYSIS CRITICAL CONTROL POINT (HACCP) CERTIFICATION OF MICRO AND SMALL SCALE FOOD COMPANIES IN THE PHILIPPINES. MATTER Int. J. Sci. Technol. 2, (2016).

12. Dzwolak, W. HACCP in small food businesses The Polish experience. Food Control 36, 132-137 (2014).

13. Garayoa, R., Vitas, A., Díez-Leturia, M. \& GarcíaJalón, I. Food safety and the contract catering companies: Food handlers, facilities and HACCP evaluation. Food Control 22, 2006-2012 (2011).

14. Green, R. \& Kane, K. The effective enforcement of HACCP based food safety management systems in the UK. Food Control 37, 257-262 (2014).

15. Karagozlu, N., Karagozlu, C. \& Ergönül, B. A model HACCP plan for small-scale manufacturing of tarhana (a traditional Turkish fermented food). Bulg. J. Agric. Sci. 15, 501-513 (2009).

16. Wallace, C., Holyoak, L., Powell, S. \& Dykes, F. Rethinking the HACCP team: An investigation into HACCP team knowledge and decision-making for successful HACCP development. Food Res. Int. FOOD RES INT 47, (2012).

17. (a, Y., Sulieman, A. M., (a, A. M., Houceine, B. \& Salghi, R. Exploring Idiosyncrasies and Potentialities of HACCP Team Across the Sharjah Food Industry, UAE. Mor. J. Chem. $3 N^{\circ} 1$ 136-141 3, 136-141 (2015).

18. Anandappa, A. Evaluating Food Safety Systems Development and Implementation by Quantifying HACCP Training Durability. (2013).

19. Kausar, H., Parveen, S., Saeed, S., Ishfaq, B., \& Ali, M. A. Development and standardization of ready to serve Aloe vera lemon functional drink. J. Environ. Sci. Toxicol. Food Technol. 10, 44-52 (2016).

20. Sasikumar, R. Preparation of therapeutic RTS beverage from aloe vera gel and aonla fruit juice and evaluation of storage stability. Asian J. Dairy Food Res. 34, 151 (2015).

21. BPOM (Badan Pengawas Obat dan Makanan). Peraturan Kepala BPOM RI No. HK.03.1.23.04.12.2206 Tahun 2012 Tentang Cara Produksi Pangan Yang Baik Untuk Industri Rumah Tangga. http://jdih.pom.go.id/showpdf.php?u=HzfTWcV RSEozXrbdVtEwFVOWM5\%2BIRyY9TI\%2BpEmsA HJI\%3D. (2012). 
22. Sutton, S. The environmental monitoring program in a GMP environment. J. GXP Compliance 14, 22-30 (2010).

23. BSN (Badan Standardisasi Nasional). SNI 7388:2009 Mengenai Batas Maksimum Cemaran Mikroba dalam Pangan. (2009).

24. Yunus, R; Syam, H. Pengaruh persentase dan lama perendaman dalam larutan kapur sirih $\mathrm{Ca}$ $(\mathrm{OH}) 2$ terhadap kualitas keripik pepaya (Carica papaya L.) dengan vacuum frying. J. Pendidik. Teknol. Pertan. 3, 221-233 (2018).

25. FAO (Food and Agriculture Oranisazation). Food Handler Manual: Instructor. (2017). 